Article

\title{
Fostering Cross-Sector Collaboration to Promote Innovation in the Water Sector
}

\author{
Lorenzo Compagnucci * (D) and Francesca Spigarelli ${ }^{\mathbb{D}}$ \\ Department of Law, University of Macerata, Piaggia della Libertà, 2, 62100 Macerata, Italy; \\ francesca.spigarelli@unimc.it \\ * Correspondence: lorenzo.compagnucci@unimc.it; Tel.: +39-071-9160014
}

Received: 24 October 2018; Accepted: 9 November 2018; Published: 12 November 2018

check for updates

\begin{abstract}
Ongoing global climate change, growing population and the intensification of economic activities, increase pressure on water resources, a situation many see as a water governance crisis. Water-related issues are becoming a limiting factor for sustainable economic growth and require a collaborative and interdisciplinary approach, to foster innovative solutions. This paper provides an evidence-based contribution to understanding Triple Helix Model (THM) relations and the path to innovation policy in the water sector. The analysis focuses on the interaction between university-industry-government, with specific reference to the Murcia region in Southeast Spain. This region combines a chronic shortage of water and a leading role for agriculture. Starting from the experience of a researcher, working for the General Water Council of the Murcia Region, this paper is based on both desk research and in-depth personal interviews with representatives of THM actors. In addition, a questionnaire was forwarded to all those companies in charge of providing water services in the Murcia region. The study has found that stakeholders are not fully cooperative in seeking innovation. The main challenges are the renewal of water-related facilities and the improvement of remote control systems, denitrification and desalination technologies and achieving better energy efficiency. To this aim, THM approach is suggested as a source of local innovation policies, identifying a series of tools to foster a collaborative approach.
\end{abstract}

Keywords: collaboration; innovation; Spain; sustainability; Triple Helix Model; water policy; water resources

\section{Introduction}

Water is irreplaceable. It is a pivotal resource for human life, nature and the economy [1-3]. As recently stated by the United Nations, water represents a human right [4]. On the one hand, water is only renewable if well managed [4,5]. On the other, the water sector is entering a period of profound change as it faces environmental challenges at both local and global levels. Indeed, freshwater constitutes only about $2 \%$ of the water on the planet and competing demands may lead to an estimated 40\% global water supply shortage by 2030 [1]. The World Economic Forum has identified the water crises as the top global risk for the next decade [4]. Thus, urgent action is needed to tackle emerging issues [2].

Looking back, European countries have a long history of water protection and reuse. In fact, rainwater reuse has been performed since Minoan times, ca. 3000-1100 BC Waste water reuse was common in Ancient Greek and Roman civilizations as well [6]. Nowadays, despite stringent regulations and systematic efforts for water protection, water resources are increasingly under pressure [7]. According to the European Environment Agency [8], freshwater resources are seriously stressed in several EU regions. There is a mismatch between demand for and the availability of, water resources across both temporal and spatial scales [9]. 
The phenomenon of water scarcity also has serious consequences in the economic context: water is vital for a wide range of activities, including agriculture, power generation, public water supply and manufacturing. In Europe, agriculture accounts for $36 \%$ of total annual water use, followed by public water supply (32\%) [9]. Moreover, in the 28 Member States, approximately $81 \%$ of the freshwater involved for energy production, agriculture, public water supply and industry, originates in surface water bodies, with groundwater being the primary source for public water supply $[8,10])$. At the same time, water is, alarmingly, becoming a limiting factor for sustainable economic growth, employment and development [11].

European sustainable growth should come from innovation in products, services and business models: eco-industries play a crucial role in developing innovative solutions. The water industry is a key component within the eco-industrial landscape and it is profitable. Indeed, the world water market is rapidly growing: it is expected to reach 1 trillion Euro by 2020 [12]. In particular, water reuse technologies represent a profitable sector for further innovation [13]. However, European water-related firms often fail to achieve their full innovative potential. Also, Europe usually does not turn knowledge into added value for society and markets [2,13-15].

In this context, the role of regions in dealing with innovation policies has recently increased [16,17]. As argued by Kohler-Koch [18], innovation processes take place across national boundaries, through cooperative arrangements between regions and firms [19]. Hence, the Triple Helix Model (THM) of university-industry-government relations is fundamental for improving the conditions for innovation in a knowledge-based society [20]. Unlocking the potential for innovation in the field of water could significantly contribute to job creation and competitiveness. It has been estimated that, in Europe, a $1 \%$ increase in the growth rate of the water industry could create up to 20,000 new jobs [12].

In response to the economic downturn and environmental challenges, the THM is being adopted as a source of inspiration for local development policy [21]. The model has been extended from university to policymaking arenas. It is a point of reference for designing policies aimed at enhancing the conditions supporting innovation [22]. In particular, innovation in the water sector is supported by an EU funding programme, Horizon 2014-2020: water is focused upon with the aim of bringing innovative solutions to the market [23].

A large body of the literature has stated that a lack of efficacy in water governance embodies one of the main reasons for water-related issues [3,21]. Climate change, land use, economic activities, urban development and demographic growth, negatively impact on water status as well [1]. Moreover, four major issues are emerging at the global level: efficiency, equity, sustainability and security of the water supply [24]. These complex challenges are interlinked and could be solved by fostering a collaborative approach between local actors. To date, much of the research carried out has focused on justifying the reasons for collaborating rather than on understanding what triggers the formation of a Triple Helix (TH) system in the water sector. There is a coordination gap between companies, academia and government and a lack of alignment among their targets [25]. Indeed, more sustainable water management has been identified as one of the improvements that the water sector will have to face in the short term [26]. Furthermore, the question of how stakeholders can improve the cooperation to accelerate innovation in water sector has been underexplored. The need for innovative solutions to deal with water challenges is undeniable, as it is clear that continuing a "business as usual" approach will not be sufficient [3].

As the literature has described the THM and the reasons for collaborating, this paper is an exploratory study which tries to contribute to the understanding of how companies, universities and governments are cooperating and how they can foster innovation and face water-related challenges. Using a case study of the Murcia region in Southeast Spain, this research will try to demonstrate what both triggers and limits, stakeholders' interactions to innovate and to respond to market needs, thus contributing to economic and social growth. The case study protocol is based on Yin [27] and Stake [28]: an action research approach has been adopted, one which includes an explanation of the researcher's reasons for choosing a given topic. The case was initially selected because the 
researcher was seconded to the General Water Council of the Murcia Region (Consejería de Agua, Agricultura, Ganadería y Pesca de la Región de Murcia), under the Horizon 2020-Marie Sklodowska Curie Actions-RISE, "ALICE-AcceLerate Innovation in urban waste water management for Climate changE." The secondment allowed the researcher to interact closely with the companies, universities and innovation centres involved in water sector in the Murcia region. This region has a chronic shortage of water, yet agriculture plays a leading role in the local economy, it also has one of the highest rates of water reuse within Spain and in Europe. The THM was applied to this context to identify actors innovating in the water sector. The THM made both the challenges addressed by stakeholders and the factors hindering a collaborative environment to promote innovation more understandable. The case selected offers an interesting point of reference when facing issues with similar features elsewhere.

This exploratory study is grounded on desk research, questionnaires and personal in-depth semi-structured interviews, which were carried out at the regional level with key informants: representatives of public and private companies, innovation centres, government and universities. The paper addresses the following research questions:

- to what extent are actors of the Triple Helix system involved in the water sector in the Murcia region?

- what are the key challenges in the water sector in the region?

- why and how, can and should actors create a collaborative environment to innovate?

Answering such questions will generate important insights for increasing the capacity and effectiveness of Triple Helix (TH) actors to work collaboratively when addressing water-related challenges. The analysis offers an insight into the current constraints and the efforts of local stakeholders to innovate, so the intended audience for this paper is policy makers and those involved in the water industry. Researchers, seeking information on THM, could find this research useful.

The paper is structured as follows. Section 2 offers an overview of the water industry in Europe and Spain. It also reviews the literature of the THM of university-industry-government relations, emphasising the strategic role of the model in water sector innovation. Section 3 focuses on methodology, namely the context of study, the case study, model and data collection. The discussion sheds light on the role of TH actors in the Murcia region and on innovation challenges and illustrates key features emerging when developing a collaborative approach and in policy building. The conclusion and avenues for future research end the paper.

\section{Background and Theory}

\subsection{The Water Industry in Spain}

Water is an irreplaceable resource which contributes to economic growth. As such, avoiding the loss of that resource can deliver economic benefits [9]. In 2030, water demand will be higher than 30 years before and is predicted to increase by $55 \%$ worldwide by 2050 . Linked with rapid urbanization, the increase in demand arises mainly from manufacturing $(400 \%)$, electricity $(140 \%)$ and domestic use $(130 \%)[29,30]$. Furthermore, water consumption for irrigated agriculture and recreational activities contribute to the intensified pressure on water resources $[7,11,31]$.

In recent years European water policy has acted to improve water quality and management. Indeed, increased interest in water quality stemming from the Water Framework Directive (WFD) has led to important questions in relation to policies that especially address nutrient loadings. It should be considered that nutrient loadings in water ecosystems leading to algal blooms may cause detrimental impacts on fisheries, biodiversity and water clarity [32]. According to recent data, surface water bodies expected to be in 'good status' have increased from $43 \%$ in 2009 to $53 \%$ at present. However, the target set for 2015 for all aquatic ecosystems to have achieved 'good status' has not yet been achieved [33]. Indeed, water scarcity, droughts and pollution, are already affecting one third of EU territory [1,2] Changes in water resources are particularly relevant in areas where water availability is a limiting 
factor for economic development. Also, the negative trend in droughts and floods will worsen in the future, impacting on sustainability, quantity, quality and management of water resources $[7,31]$. This is especially the case in the Mediterranean basin, in particular in Southern European countries like Italy, France and Spain $[1,7,31,33]$.

The overall impact of the 2003 drought on the European economy has been estimated at a minimum of 8.7 billion Euro, measured as the estimated losses directly resulting from the drought. The direct effects of droughts, such as damage to agriculture and agriculture-related industries, are more obvious but the indirect effects, such as a reluctance to invest in an at-risk area, can produce serious economic effects. A $1 \%$ increase in the area of the country affected by drought can slow a country's gross domestic product (GDP) growth by $2.7 \%$ per year [13,34]. During the period 2001-2006, economic damage was estimated to be 37.2 billion Euro, accounting for nearly $40 \%$ of the total economic damage from droughts over the last 30 years [35].

The water industry is increasingly important for Europe [4], with about 9000 small and medium-sized enterprises (SMEs). Eurostat has recently highlighted that up to $98.8 \%$ of European companies in the sector of water supply, sewerage, waste management and remediation are considered SMEs (26). In addition, the water industry employs about 600,000 full-time workers [4]. The European waste water sector as a whole, including exports, creates a production value of about 96 billion Euro per year and an added value of about 41 billion Euro per year [4]. Moreover, if only the construction of infrastructure to provide quality waste water services is considered, it represents an added value of about 15 billion Euro per year [23]. It has been noted that a $1 \%$ increase in the rate of growth of the water industry in Europe could create between 10,000 and 20,000 new jobs [1].

More than in other Member States, in Spain (Table 1) the development of the economy cannot be separated from the work carried out by early civilizations and right up to modern times, to more effectively manage water. National water planning in Spain has 'dogged successive governments' ever since the first incarnation of a national hydrological plan in 1933 [36]. Agriculture, industries related to agriculture, tourism and energy production, heavily depend on water. Gross freshwater abstraction by sector during the period 2000-2010 [37] shows that irrigation accounts for $63 \%$ of all water withdrawal; water cooling for power generation for $19 \% ; 16 \%$ for public water supply; and $2 \%$ for the manufacturing industry [13].

Table 1. Water sector in Spain: an overview.

\begin{tabular}{ll}
\hline Population (inhabitants) & $46,000,000$ \\
Drinking water network length per capita & $4.8 \mathrm{~m}$ \\
Waste water network length per capita & $3.54 \mathrm{~m}$ \\
Average residential consumption & $139 \mathrm{~L} / \mathrm{cap} / \mathrm{d}$ \\
Average price of water & $1.78 \mathrm{Euro} / \mathrm{m}^{3}$ \\
\hline \multicolumn{2}{c}{ Source: author's elaboration of [36]. }
\end{tabular}

As a result of low and variable rainfall which affects $2 / 3$ of the country (Table 2) [38], water has always been a limiting factor for the country's economic development [9].

Table 2. Hydrology of Spain: an overview.

\begin{tabular}{ll}
\hline Surface area & $509.000 \mathrm{~km}^{2}$ \\
Average annual precipitation & $649 \mathrm{~mm}$ \\
Average annual precipitation Vigo (Northwest Spain) & $1.909 \mathrm{~mm}$ \\
Average annual precipitation Almería (Southeast Spain) & $196 \mathrm{~mm}$ \\
Average annual runoff & $220 \mathrm{~mm}$ \\
Average annual runoff of the Cantabrian coast (Northern Spain) & $700 \mathrm{~mm} /$ year \\
Average annual runoff of the Segura district (Southeast Spain) & $<50 \mathrm{~mm}$ \\
\hline
\end{tabular}

Source: author's elaboration of [36]. 
It should be considered that Spanish companies have developed cutting-edge technologies and services throughout the whole water cycle and exported them to Europe, South America, Africa and Australia. Indeed, Spain is one of the world leaders in water reuse, desalination and waste water regeneration technologies. Moreover, it is the fifth country worldwide for reuse capacity ( $500 \mathrm{hm}^{3} /$ year) with more than 320 Refined Water Regeneration Stations (ERA). Spain has a desalination capacity close to 3 million $\mathrm{m}^{3}$ /day as well. Furthermore, the country is a frontrunner in the maintenance of infrastructures related to water management, including: dams and reservoirs, water supply systems, water purification stations, conduction and distribution networks linked to irrigable areas. Also, Spain is globally recognised for its efforts to develop risk analysis software and management tools for the water sector [39].

The past and current spread of water reuse technologies in Spain has been a motor for the competitiveness of the water industry. This trend is expected to continue within and outside Europe over the next 10 years [13]. By seizing new and significant market opportunities, Spain could become a global market leader in water-related innovation and technology. In 2006, the AQUAREC project developed a model to estimate projections for water reuse in the EU by 2025 , it focuses on further development of water reuse projects and on an increase in the volume of reused treated waste water across the EU. Spain has shown the greatest reuse potential, namely over 1200 million $\mathrm{m}^{3}$ /year [9].

The European Innovation Partnership on Water [2] has emphasised the potential market for innovation in water reuse and recycling, both through implementing technological solutions and by adopting policy measures. There are also significant opportunities for new business models and governance structures which could prevent defragmentation and reorganise/redesign water, rainwater-harvesting and groundwater processing on site. The economic potential of energy savings in water treatment processes and transport is important as well. The smart water concept has considerable potential in Information Communication and Technology (ICT), software and analytics, hardware and infrastructure development. Nevertheless, massive investment is needed to build, operate, maintain and adapt water infrastructures. In this context the European cohesion policy has made a significant contribution to improving the water environment in the last financial period (2007-2013) [33]. As reported by WRc [40], the EU Cohesion Policy's total funding allocations for water Intervention Fields (IFs) 2020-2022, in the financing perspective 2014-2020, amount to over 14.7 billion euro. Table 3 illustrates the measures planned in the Spanish water management sector. Measures can be divided into drinking water-related measures (IF 20), waste water-related measures (IF 22) and more general water management and protection measures that primarily aim to conserve drinking water (IF 21).

Table 3. Spain: Cohesion Policy funding allocations to the IFs 2020-2022.

\begin{tabular}{cccccccc}
\hline $\begin{array}{c}\text { Allocations IF 20 } \\
\text { Provision of Water for } \\
\text { Human Consumption }\end{array}$ & $\begin{array}{c}\text { Allocations to IF 21 Water } \\
\text { Management and Drinking } \\
\text { Water Conservation }\end{array}$ & $\begin{array}{c}\text { Allocations to IF 22 Waste } \\
\text { Water Treatment }\end{array}$ & Allocations to IFs 20-22 \\
\hline EUR & $\%$ & EUR & $\%$ & EUR & $\%$ & EUR & $\%$ \\
\hline $98,995,352$ & $5.6 \%$ & $48,546,556$ & $1.6 \%$ & $1,090,939,070$ & $10.9 \%$ & $1,238,480,978$ & $8.4 \%$ \\
\hline \multicolumn{7}{c}{ Source: author's elaboration of [40]. }
\end{tabular}

Despite these efforts, water reuse is still regarded as a costly alternative with low returns on investment, especially when compared to abstraction from water bodies [9]. There is a marked contrast between financially cheap but increasingly scarce sources (i.e., groundwater) and expensive, albeit abundant, alternatives (i.e., desalinated water). Path dependency tends to favour the use of the former, thus reinforcing unsustainable trends. The latter is then used for emergency situations-but the loss of economies of scale makes these sources financially less competitive $[9,13]$. Given the limited possibilities of increasing its water supply, Spain should reduce its ecological footprint per capita, whilst retaining its economic development. The country has to produce an increasing volume of goods and services with less water. Therefore, it is urgent to enhance greater efficiency in the water sector through innovative technologies and new business models [24,41]. 


\subsection{The Triple Helix Model (THM)}

In the light of the above described framework, the water sector is entering a period of profound change, as it must face complex, interdisciplinary issues, which require a collaborative approach to promote innovative solutions. If water-related firms were able to achieve their full innovative potential, the water industry could contribute considerably to sustainable economic growth in both Spain and Europe. Indeed, the Triple Helix Model (THM) industry-university-government relations could be applied to improve the conditions for innovation by promoting a collaborative environment, to bridge the gap between research outcomes and their commercialisation.

\subsubsection{University-Industry-Government Relations}

Etzkowitz and Leydesdorff [21] introduced the THM to explain structural developments in knowledge-based economies [42]. The transition to a knowledge society should be grounded on a hybridization of university, government and industry. This allows a systemic framework for the generation, diffusion and exploitation of knowledge. A blurring and overlapping of traditional university-industry-government boundaries is needed as well [41,43]. As emphasised by Mroczkowski and Miller [44], both Lowe [45] and Sábato and Mackenzi [46] should be included among the precursors of the THM. These latter analysed the move from a leading industry-government "dyad" as a key feature of industrial society, to that of an emerging "triad" between university, industry and government. The THM is a key component of any national or multi-national innovation strategy [19], as well as being important for reducing factors hindering regional development [47]. The model illustrates the formation and consolidation of learning societies, which are rooted in knowledge production and dissemination and a well-articulated relationship between university, industry and government [20].

THM relations have overtaken previous models, whether laissez-faire or socialist, in which either the economy or polity played a leading role [38]. In a statist regime, government drives universities and industry and, in its statist role, a regional government could introduce an institutional framework made up of regulations and policies, managing the activities of the other actors $[48,49]$. Under a laissez-faire regime, industry is the front runner, with the other two institutions acting as ancillary structures. Whereas, in our view, a knowledge-based society is mainly grounded on universities and other knowledge-producing actors, even taking the leadership in joint initiatives with companies and government, thus delineating a balanced model [47,48].

In this model, industry is the locus of production, government acts as the source of contractual relations which safeguard interactions and exchange and, universities are in charge of creating new knowledge and technology. The actors interact to foster innovation which will be transferred, at the local level, in terms of economic growth through a top-down approach [20]. The actors usually belong to a regional development network and their collaboration is multilateral [50]. To date, much of the research has focused mainly on justifying the reasons for collaborating. Ranga and Etzkowitz argue that there remains a lack of understanding of what triggers and limits the formation of a TH system between the actors-helices [41]. The core element of the model is the reciprocal links between the three of them. These consist of different kinds of collaborations, occurring at various levels of organizations, which, furthermore, may evolve from temporary cooperation into strategic alliances $[19,51,52]$ (Figure 1). 


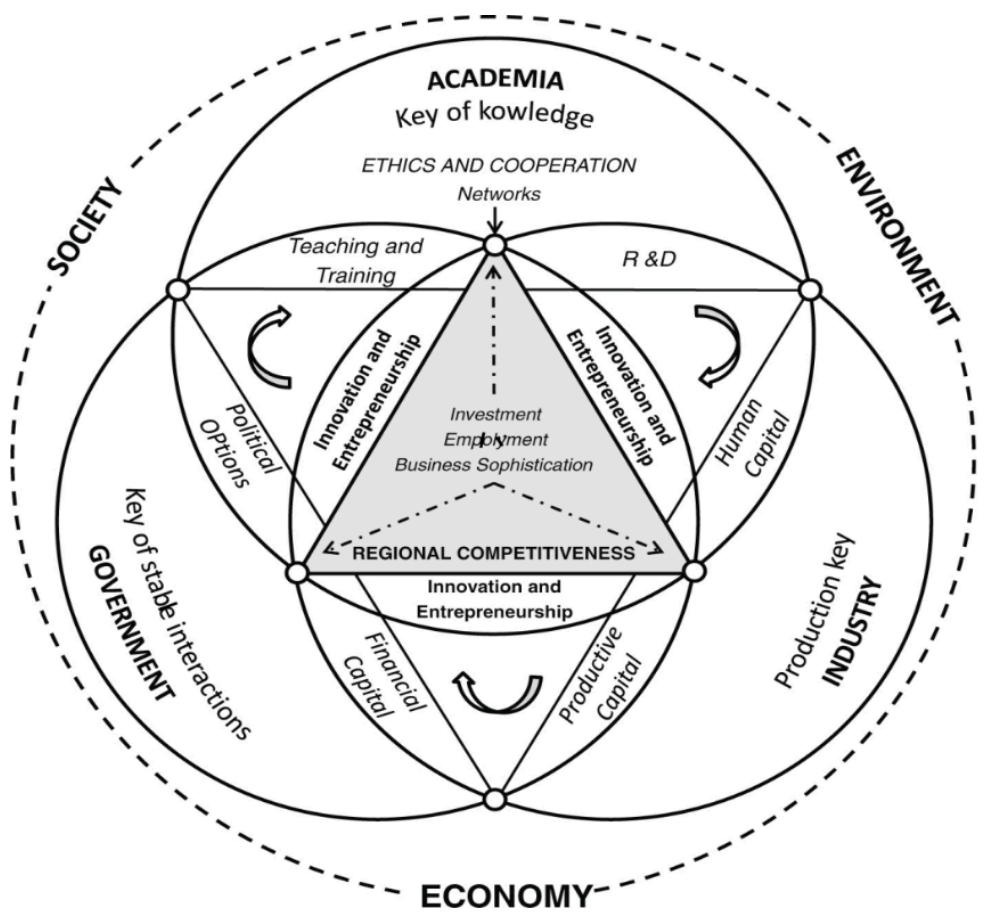

Figure 1. Triple Helix Model for innovation.

\subsubsection{The Quest for Innovation}

Innovation plays an essential role in boosting opportunities for a dynamic economy, as well as enhancing society [53]. As emphasised by Birkner et al. [54], innovation is an important source of national and regional economic growth. Innovation processes take place across national boundaries, through cooperative arrangements among regions and firms [18,19]. According to the literature, innovation is the ability to do things in a new way [55], a change that unveils new dimensions of performance [56], or a creative idea [57]. Porter [58] argues that innovation consists of a series of small development steps which provide the opportunity for continuous competitive advantage. More recently, the European Committee of the Regions [16] has stated that innovation is a multi-dimensional concept which includes the actions required to create new ideas, processes or products that, once implemented, lead to positive effective change for the business. The effects are beneficial externalities for the market, the territory and the society in which the business operates.

The EU is particularly effective in producing innovation but not as effective in commercialising it. Europe often fails to turn this knowledge into added value for society and markets. Crossing this "valley of death" requires an integrated approach of demonstrations and scaling-up projects, increasing acceptance of new technologies, public-private cooperation and appropriate investments [2,14,15]. Eurostat (http:/ / epp.eurostat.ec.europa.eu/statistics_explained/index.php/R_\%26_D_expenditure) observed that, in 2010, gross domestic expenditure on Research \& Development (R\&D) + Innovation (I) activities in the European water sector amounted to $2.0 \%$. The highest level was in Finland 3.9\%, whereas it was $0.2 \%$ in Albania, $0.5 \%$ in Cyprus, $1.4 \%$ in Spain, $1.6 \%$ in Portugal and 2.3\% in France [7]. Despite these efforts, innovation-driven development requires certain kinds of activities, actors and certain collaborative practices as well.

In this framework, the THM has increasingly emerged as beneficial [21,48,50,59]. Indeed, the THM of university-industry-government interactions is the key to improving the conditions for innovation in a knowledge-based society [20]. The model is founded on the idea that innovation is the outcome of an interactive process involving different spheres of actors, each contributing according to their 'institutional' function in society. Contribution to innovation is envisaged in terms of sharing knowledge and transferring know-how, with helix models assigning and formalising a role for each 
sphere in supporting economic growth through innovation [22]. A large body of the literature argues that successful TH synergies depend on how political organisations, industry and academia, work together to enhance the local conditions for innovation [44]. However, the common orientation of these actors is essential for innovation [21,25].

In response to the economic downturn and emerging environmental challenges, the THM is being adopted as a source of inspiration for local development policies [21]. The model has been extended from universities to policymaking arenas. It has become a point of reference for the design of policies aimed at improving the conditions for innovation [22]. Local innovation policies are being designed, amplifying the importance of the THM [21,60]. In the THM, innovation starts from a new idea or an experience. The idea makes links with other firms. The whole process can also begin with reverse systems such as, an individual at a company might have an idea for a technical process innovation and refer back to the university [48]. Next, innovation is supported by a set of factors that are transversal to the economy, which may include: human and financial resources allocated to scientific and technological advances; levels of technological sophistication; public policies affecting innovation related activities; intellectual property protection; fiscal incentives for innovation and, enacting and effectively implementing antitrust and abuse of power legislation [61,62].

While the need for collaboration in order to promote successful innovation has been analysed in various innovation-related studies [63-65], the advantage of the THM is that, by simplifying the constellation of actors and their relations, it offers a simple framework for examining innovation networks [51]. This model can also be applied to complex sustainability issues such as water challenges, namely water scarcity and droughts. Individuals and organisations need to be able to generate and exploit knowledge in order to develop solutions that address these challenges [66-68]. In this context, actors should follow a transdisciplinary path [68].

Rather than just the development of new products, innovation is, here, the creation of new arrangements between institutions which enhance the conditions for innovation. The introduction of organizational innovations, new social arrangements and new channels for interaction are as important as the invention of physical devices for speeding up the pace of innovation [24]. The European Innovation Partnership on Water (EIP Water) was established to unlock the full potential of the EU water sector, [13]. However, while there are many opportunities for innovations based on experience within the EU, there is a need to look, learn and develop strategic partnerships with regions already facing the challenges of Europe's future [2]. Indeed, water innovation takes place by means of an increased level of integration between users, water managers, planners, policy makers and academics across spatial scales $[7,69]$.

The transfer of knowledge and innovation among water stakeholders is rather difficult. The reason being not only market competition but the lack of a good governance model [2,7]. Facing water challenges in the most cost-effective way requires investing in large scale innovative solutions to improve resource efficiency [23]. In particular, greater emphasis on water reuse could lead to the introduction of new technologies and techniques, thus providing business opportunities for the water industry and other relevant water-related industries such as agriculture and horticulture [13]. To sum up, innovation is a strategic driver for fostering water industry development. Unlocking the potential for innovation in the field of water could significantly contribute to job creation and to competitivity. It has been estimated that, in Europe, a $1 \%$ increase in the growth rate of the water industry could create up to 20,000 new jobs [12].

\section{Materials and Methods}

\subsection{Context of Study}

The empirical context of this study is the Murcia region which is included in the Segura River Basin District (RBD—Confederación Hidrográfica del Segura). Figure 2 shows the position of Murcia region (ES070) in Southeast Spain. In this region, government, municipalities, private innovation centres, 
universities and both public and private companies, are all active in the field of water management and innovation. Numerous public-private collaborations have been established to face water challenges in the region, which is characterised by structural water scarcity, a decrease in rainfall, rising temperatures and a high frequency of maximum events (floods and droughts). These features depict the water deficit in Southeast Spain, where merely exploiting conventional water resources, such as surface water (rivers, reservoir), ground water (aquifers) and external water (transfers) is, simply, not enough. In response to the chronic water deficit, local stakeholders have, of necessity, resorted to the diversification of sources as well as to the incorporation of non-conventional resources, including the reuse of reclaimed water and of desalination [70]. Consequently, the region has a high level of innovation in the water sector: it has the highest rates of water treatment and of reuse both in Spain and in Europe [71].

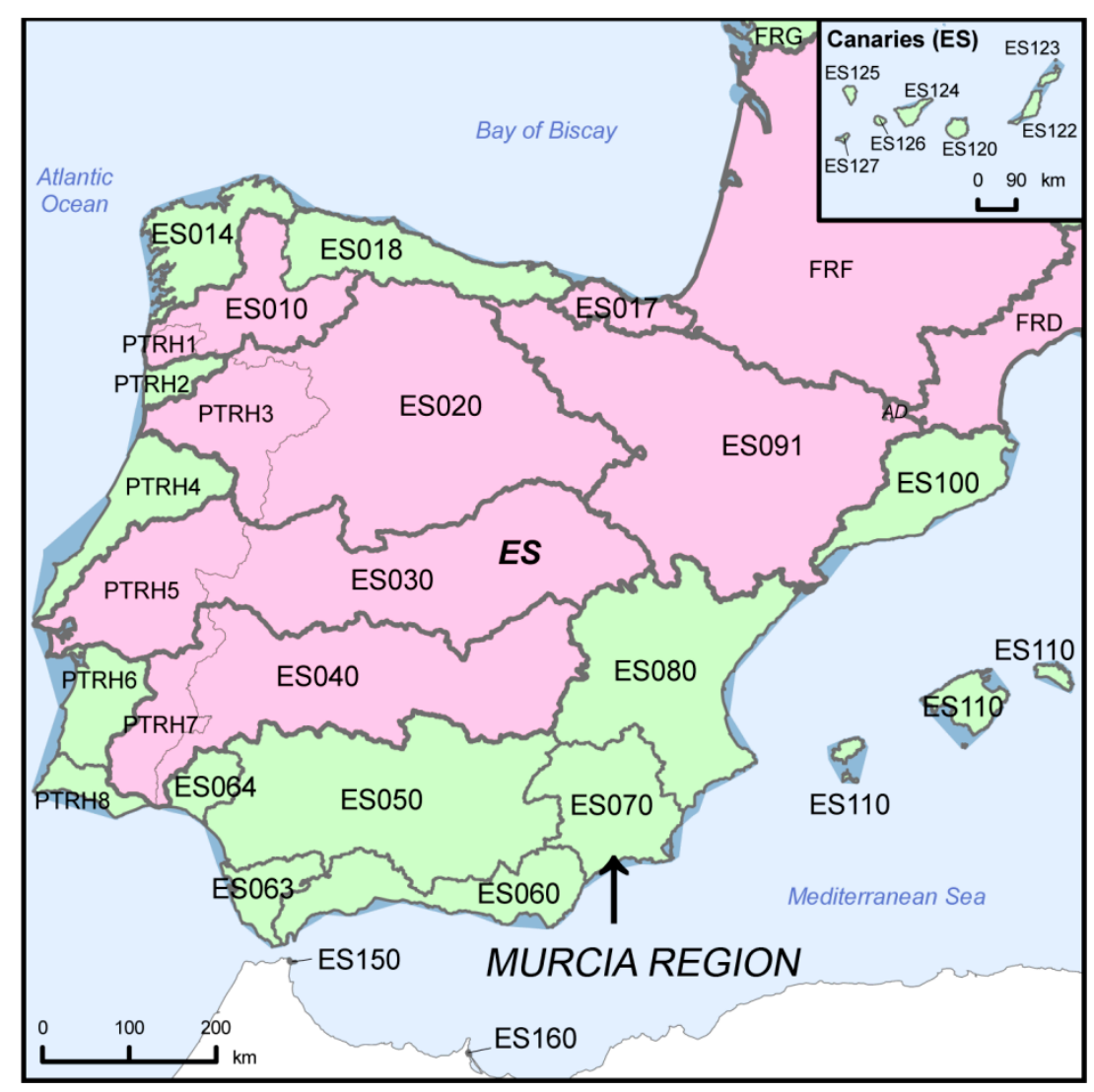

Figure 2. Map of River Basin Districts including Segura RBD (ES070). Source: Water Information System for Europe.

The Murcia region boasts a unique model of water reuse (more than $90 \%$ ) and of environmental protection [39]. The Basin extends over an area of approximately $20,234 \mathrm{~km}^{2}$, of $19,025 \mathrm{~km}^{2}$, if one considers only the continental part and excludes coastal waters. This area includes 132 municipalities, which are divided into four autonomous communities (comunidades autónomas): Región Murcia, Andalucía (provincias de Jaén, Granada y Almería), Castilla-La Mancha (provincia de Albacete) and Comunidad Valenciana (provincia de Alicante). These autonomous communities have an estimated population of 1,964,636 and a density of $103 \mathrm{hab} / \mathrm{km}^{2}$. This study only considers the Murcia region, which consists of 45 municipalities with 1,470,273 inhabitants, corresponding to $73.2 \%$ of the whole population living within the RBD. The Murcia region covers $75.5 \%$ of the RBD, with a population density of $132 \mathrm{hab} / \mathrm{km}^{2}$.

Table 4 gives information on the number of water bodies within the Segura RBD.

The forecast for water bodies status improvement in 2021 and 2027 is shown in Table 5. 
Table 4. Segura RBD: surface water bodies, groundwater bodies and their dimensions.

\begin{tabular}{|c|c|c|c|c|c|c|c|c|c|c|}
\hline \multirow{3}{*}{ RBD } & \multicolumn{8}{|c|}{ Surface water } & \multicolumn{2}{|c|}{ Groundwater } \\
\hline & \multicolumn{2}{|c|}{ Rivers } & \multicolumn{2}{|c|}{ Lakes } & \multicolumn{2}{|c|}{ Transitional } & \multicolumn{2}{|c|}{ Coastal } & \multirow[b]{2}{*}{ Number } & \multirow[b]{2}{*}{$\begin{array}{l}\text { Average Area } \\
\text { (sq km) }\end{array}$} \\
\hline & Number & $\begin{array}{c}\text { Average } \\
\text { Length }(\mathrm{km})\end{array}$ & Number & $\begin{array}{l}\text { Average Area } \\
\text { (sq km) }\end{array}$ & Number & $\begin{array}{l}\text { Average Area } \\
\text { (sq km) }\end{array}$ & Number & $\begin{array}{l}\text { Average Area } \\
\text { (sq km) }\end{array}$ & & \\
\hline ES070 & 90 & 19.13 & 6 & 6.39 & 1 & 25.17 & 17 & 71.13 & 63 & 243.8 \\
\hline
\end{tabular}

Source: author's elaboration of Water Information System for Europe.

Table 5. Segura RBD: surface water bodies: overview of status in 2009 and expected status in 2015, 2021 and 2027.

\begin{tabular}{|c|c|c|c|c|c|c|c|c|c|c|c|c|c|c|}
\hline \multirow{3}{*}{ RDB } & \multirow{3}{*}{ Total } & \multicolumn{5}{|c|}{$\begin{array}{l}\text { Global Status (Ecological and } \\
\text { Chemical) }\end{array}$} & \multirow{2}{*}{\multicolumn{2}{|c|}{$\begin{array}{c}\text { Good } \\
\text { Ecological } \\
\text { Status } 2021\end{array}$}} & \multirow{2}{*}{\multicolumn{2}{|c|}{$\begin{array}{c}\text { Good } \\
\text { Chemical } \\
\text { Status } 2021\end{array}$}} & \multirow{2}{*}{\multicolumn{2}{|c|}{$\begin{array}{c}\text { Good } \\
\text { Ecological } \\
\text { Status } 2027\end{array}$}} & \multirow{2}{*}{\multicolumn{2}{|c|}{$\begin{array}{c}\text { Good } \\
\text { Chemical } \\
\text { Status } 2027\end{array}$}} \\
\hline & & \multicolumn{2}{|c|}{$\begin{array}{l}\text { Good or } \\
\text { Better } 2009\end{array}$} & \multicolumn{2}{|c|}{$\begin{array}{l}\text { Good or } \\
\text { Better } 2015\end{array}$} & \multirow{2}{*}{$\begin{array}{c}\text { Increase } \\
\text { 2009-2015 } \\
\%\end{array}$} & & & & & & & & \\
\hline & & No. & $\%$ & No. & $\%$ & & No. & $\%$ & No. & $\%$ & No. & $\%$ & No. & $\%$ \\
\hline ES070 & 114 & 52 & 45.6 & 58 & 50.9 & 5.3 & 95 & 83.3 & 101 & 88.6 & 114 & 100 & 114 & 100 \\
\hline
\end{tabular}

The above data highlight the recent intense urban and demographic growth in the Murcia region. As the area selected is highly populated, urbanisation phenomenon is considered a contributory factor to environmental issues like floods, erosion, soil contamination and degradation of aquatic systems [72]. On the other hand, wastewater treatment is increasingly important for both public hygiene and flooding prevention [73]. In addition, agriculture plays a dominant role in the region, which is the leading Spanish exporter of fruit and vegetables. Agriculture is heavily dependent on water resources. Indeed, agriculture accounts for up to $80 \%$ of all freshwater abstractions, with food crop irrigation as the main use [13,70]. Murcia is one of the Spanish regions with the highest area of irrigated land/cultivated land (38\%). Moreover, Murcia is one of the autonomous regions with the highest share of irrigated land/total regional area $(16 \%)$, thus, one of the driest territories has the high index of water exploitation. From an economic point of view, the direct contribution of agriculture to Murcia regional output and employment is $4.2 \%$ and $4.5 \%$, respectively. Moreover, the indirect and induced impact of agriculture throughout the entire chain of production makes this industry the main player for existing income and employment opportunities [36].

These achievements in the water sector are the outcome of the efforts of local stakeholders, who have been supported by local and national governments. For example, the Water Treatment and Drainage Plan of the Murcia Region, undertaken by the Regional Government, started in 2001 after a study phase in which both European and US water-treatment systems had been analysed. Six hundred and thirty-five million Euro (co-financed by the EU) were invested in water-treatment infrastructures and 47 large waste water treatment plants, with a maximum treatment capacity of $540,000 \mathrm{~m}^{3} /$ day, were built. Thanks to this commitment, in just over 10 years, the Segura River, went from being the most polluted river in Spain, to having undetectable pollution levels in all of its sections, with an obvious improvement in both the environment and in economic activities in the area [36].

\subsection{Case Study}

The research has adopted a qualitative case study method [28] which could offer new insights and improve current theoretical knowledge [74]. A single case study approach has been used because detailed examination of the dynamic relationship between the actors in a helix model is required. Moreover, a micro level case-based study makes it possible discern the complexity of the activities which take place in a helix model [75]. Case study research is a highly qualitative form of inquiry [54]. It is often seen as a second-best choice because of the limited level of external validity it offers [49,76]. However, a case study can contribute to a greater understanding of the facts through in-depth research [62,77]. Indeed, a case study has often been considered a very suitable strategy when 
the research is exploratory, involves a contemporary phenomenon and addresses the "how" and "why" questions [27]. Furthermore, a case study makes it possible to gather insightful information in the field "face-to-face with real people" [54,78].

The case study protocol is based on Yin [27], Stake [28] and Tellis [79]: an action research approach was adopted, which includes the stated reason why the researcher chose a given topic. This case was selected because the researcher was working for the General Water Council of the Murcia Region (Consejería de Agua, Agricultura, Ganadería y Pesca de la Región de Murcia) and interacting closely with public and private companies, universities and innovation centres involved in the water sector. The Murcia region brings together the common efforts of local stakeholders to innovate in the water sector. This case study offers an interesting point of reference for others facing issues with similar features elsewhere.

\subsection{Model}

The THM $[19,21,47,48]$ was used to identify the actors engaged in the water sector in Murcia region, namely 13 private and public companies, 3 universities, 3 research-innovation bodies, one regional government and 45 municipalities. The approach meant observing the relations established between the various actors. Furthermore, the model has also made it possible to understand which challenges are emerging, what triggers collaboration between local stakeholders and, how cooperation could be undertaken to encourage innovation in the water sector. The interdisciplinary and collaborative framework was applied to water-related issues in the Murcia region as an example of a complex problem-solving basis for seeking innovation policies to diverse challenges. The link between a case study focus and constructing innovation policies has been developed in close relation to the cross-sectorial approach amongst stakeholders. Figure 3 illustrates the main actors of the TH system in the water sector.

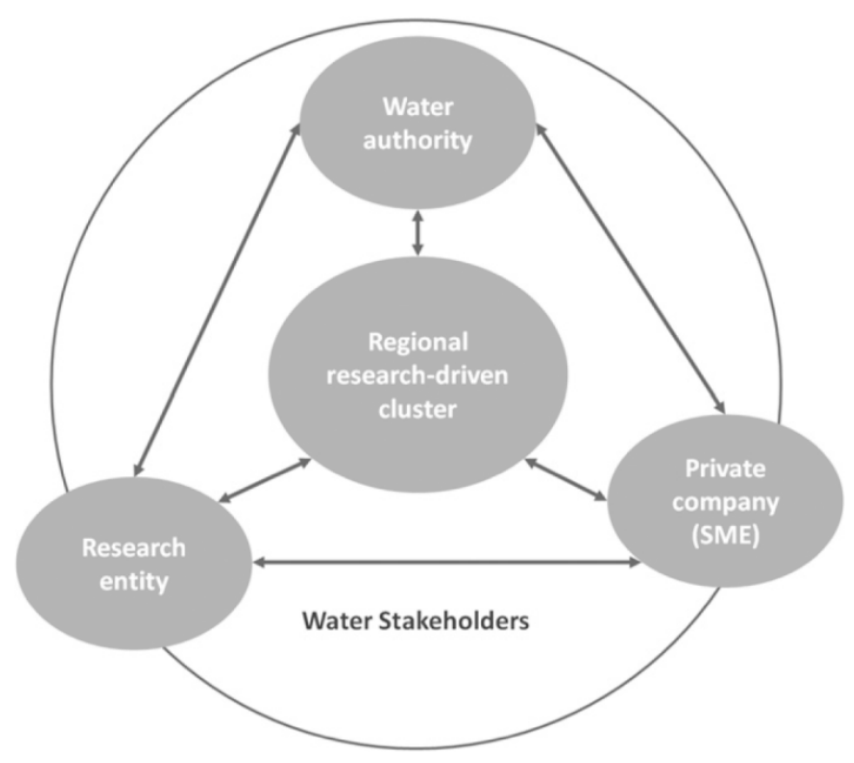

Figure 3. Triple Helix Model in the water sector. Source: [7].

\subsection{Data Collection}

The exploratory study was structured as follows: an initial phase of brainstorming to glean insights from some informal interviews carried out with civil servants working for the General Water Council of the Murcia Region. This phase enabled contextualisation of the study of the situation in the region. Information was also gathered through a literature review of scientific papers. The analysis also included the regulations, policy documents and reports and the statistical data, from secondary sources, to ensure strategy triangulation [79]. 
Next, a semi-structured questionnaire was developed and tested. The questionnaire was forwarded to all those public and private companies which provide water services in the Murcia region, namely water supply, sewage, waste water treatment companies. Based on the information gathered from both the regional government and from agencies, the analysis considered all the companies (13) which are responsible for providing water services in the entire region (45 municipalities). The questionnaire was made up of 15 open-ended questions (see Appendix A). The first section of the questionnaire concerned general information about the organization: role, activities and people involved. Then, the respondent was asked to describe, evaluate and assess: their collaboration with companies, academia, innovation centres and the government and to identify factors that hindered action and identify other major needs that they felt should be met in order to encourage innovation in the water sector at the regional level. Thirteen questionnaires were sent out; 7 respondents replied the survey. To overcome language barriers, the questionnaire was forwarded in two versions: English and Spanish. Ethical principles were observed when writing the questionnaire [80].

The rigidity, limits, of the questionnaires were overcome thanks to on-site visits to water facilities and 7 in-depth personal semi-structured interviews. The interviews were carried out in May 2018 with representatives of public and private companies, innovation centres and agencies, government and universities, including Chief Executive Officer, Chief Administrative Officer, Chief Technology Officer, Chief Sustainability Officer, Chief Innovation Officer, Director of the University Institute for Water Governance and Sustainability. Starting from the questionnaire, each semi-structured interview was composed of a set of $6 / 7$ predetermined open questions. The interviews were conducted in English or Spanish and lasted approximately 70-80 min. The interviews were also recorded and transcribed verbatim.

The interviews were preceded by an informal conversation in order to make the approach more flexible and to gather the personal thoughts (and opinions) of each interviewee regarding the challenges of the water sector. Thus, the interview method made it possible to obtain valuable information because interviewees were also able to freely express their insights, reactions and concerns. Creswell [81] argues that interviews can reveal new knowledge of people's experiences and business environments, which is not available elsewhere.

The following flowchart (Figure 4) summarises the methodology applied in this work.

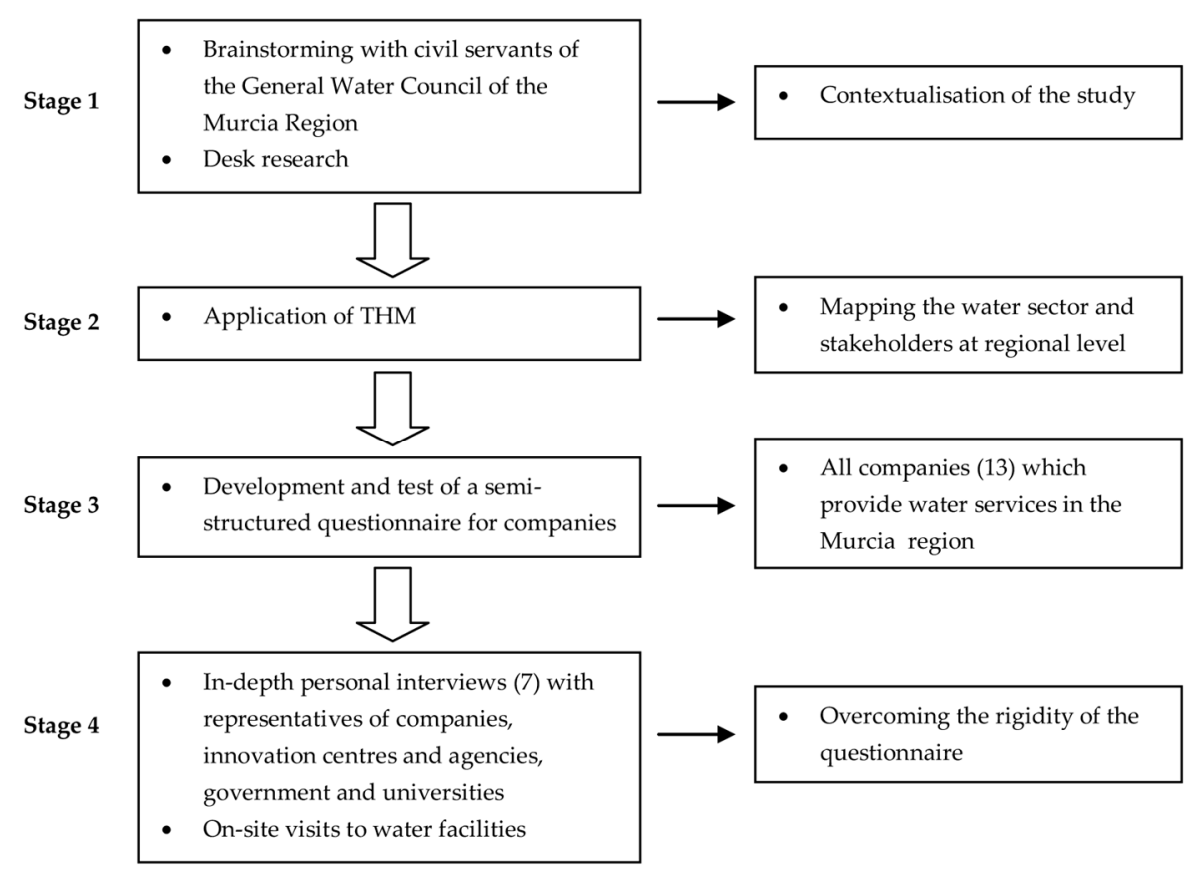

Figure 4. Flowchart of methodology. Source: authors' elaboration. 


\section{Results and Discussion: Key Emergent Themes}

\subsection{The Role of TH Actors in the Murcia Region}

A major challenge in TH relations is to develop a shared and common vision. At first sight, it sounds self-evident but it is quite complicated to identify the ambitions of multiple actors who have both collective and, also, conflicting needs and stakes. The government generally focuses on knowledge production to develop long term solutions for social problems, whereas, companies are keener on producing knowledge which offers profitable solutions for issues they face in the short term [68]. As recognised by Martins et al. [7] knowledge transfer between local stakeholders and the availability of tools for data exchange, can help to exploit existing synergies as well as lead to economic growth. However, TH relations are heavily dependent on the capacity and willingness of industries, universities and governments, to agree on a shared agenda. Thus, a collective effort towards a common goal is needed to make the water sector competitive, to achieve market uptake.

In Murcia, local government, public and private companies, universities and innovation centres are not fully collaborating to seek innovative solutions in the water sector. On the one hand, government, universities and innovation centres generally do not seek solutions in a reactive way, rather they wait for industry to do so. On the other hand, private companies are more willing to get into contact with public bodies to investigate issues and to start innovating by means of round tables and agreements. Once a collaboration begins, it becomes easier for public-private partnerships and joint projects to emerge.

Huggins et al. [82] assert that universities and research centres serve as critical institutions in shaping and transferring innovation. Indeed, universities and innovation centres in Murcia are the actors with whom companies are most engaged. Their synergy is grounded on collaboration agreements to enhance technology transfer. Also, firms and universities usually collaborate to compete in tenders and R\&D grants. Companies mainly cooperate with local universities because of the recognised prestige of their $R \& D$ departments and of their proximity. In some cases, the company establishes its own physical space within the university building to maximise the link between academia and business, nurturing the talent of young graduates and researchers who are seeking to address water-related issues. Collaboration between entrepreneurs and scholars is usually based on personal relationships and mutual trust, which develop over the years. Thus, informal contacts and highly qualified academic personnel are key features in enhancing the synergy towards innovation in the water sector, including research related to waste water treatment, water pollution reduction and desalination.

It is clear that both private technology centres and university start-ups play a very active role in developing specific stages of research and innovation, thus encouraging knowledge transfer to the market. Firms prefer to engage university start-ups for two reasons. First, university start-ups are developed within the academic arena, thus they should guarantee both an excellent level of knowledge and higher research skills. Furthermore, university start-ups focus full time on applied research, as well as on product and technology development, which is profitable for companies. On the contrary, university departments usually tend to be oriented towards basic research, aimed at publishing papers, so less useful for firms. Larsen [83] argues that a disincentive to would-be academic entrepreneurs is that basic research is often more cited than applied research where citation is a mark of academic esteem.

The reality of the stream of communication between universities and industry still leaves plenty of room for improvement. Not only do scholars and entrepreneurs focus on achieving their individual targets but also the bureaucracy involved requires a long time which hinders starting and developing joint projects, whereas companies seek profitable solutions they can develop and apply in the short term. Thus, there is a recognisable time gap between successful research outcomes and their application to the market. This gap could be partially reduced by promoting traineeships within companies: masters students and graduates could grasp business language and also understand employment market 
requirements better. Furthermore, firms have often stated that they are not willing to cooperate with departments of Social Sciences and Humanities (SSHs) because transferring knowledge from academia to the company and then commercialising research outcomes becomes too complex. However, SSHs should be reconsidered as they can make interdisciplinary challenges more understandable, especially in water-related issues, as these have an enormous impact on the economy, society and the environment. Moreover, an SSH driven collaboration between companies and universities could produce innovative problem-solving strategies that would be useful for developing new products and technologies and, would help them understand and so meet market demands in a more efficient manner.

Because Spanish water services are mainly based on delegated public management and delegated private management, private companies daily cooperate with the public authorities: both municipalities and regional governments. In particular, municipalities supervise the quality of the service offered to customers at the local level and have the legal authority to establish the quality of the water services provided. As regards regional governments, firms usually interact with civil servants and public agencies-companies to set up joint projects for innovations in the water sector; to manage business procedures; and to compete for calls for projects and grants. However, many firms are still reluctant to use digital devices in the correct way, that is, to comply with regulations introducing the digitisation of public procedures even though the adoption of digital devices and procedures is not merely obeying the Law but actually reduces the regulatory burden put on entrepreneurs. Digitisation has proved instrumental in stimulating innovation throughout society and in all sectors of the economy [84]. Indeed, it can improve business by reducing time-consuming activities, as well as fostering transparency in public-private partnership.

\subsection{Innovation Challenges}

Martins et al. [7] assert that innovation is needed to address water challenges. The combination of the promotion of research and innovation (supply side) together with a strong focus on achieving a shorter time to market for innovative products and services (demand side) is essential. The regional government of Murcia is supporting companies and universities innovating in the water sector well, by means of a variety of tools, programs and agencies. Entrepreneurs are considered key actors in the economy and employment at the regional level, partly because they speed the pace of innovation. Also, the government has started to support innovative start-ups and is helping them grow. From a general point of view, the government is increasing the finance they provide; encouraging companies to expand faster; reducing the regulatory burden, especially on entrepreneurs; and promoting synergies between knowledge institutions and the private sector, to encourage public-private partnerships.

In this context, the main challenge is to build and improve facilities for water supply, sanitation and distribution. The construction, maintenance and operating activities of water infrastructures is difficult, whether they be: dams and reservoirs; water supply systems; water purification stations; conduction and distribution networks linked to household demand, industrial use and irrigable areas. From the economic point of view, in Europe, if only the construction of infrastructure to provide quality waste water services is considered, it represents an added value of about 15 billion Euro per year [23].

Water facilities in the Murcia region, must be renewed as they are about 40-50 years old and now provide water to 1,470,273 inhabitants in 45 municipalities. However, massive investment is needed to build, operate, maintain and adapt water infrastructures in an area which covers $75.5 \%$ of the $19,025 \mathrm{~km}^{2} \mathrm{RBD}$. The Murcia region has benefited from European cohesion policy, which has made a significant contribution to improving the water environment in the last financial period (2007-2013) [33]. Despite the efforts of European and national policies, TH regional actors, both public and private, broadly agree that it is not possible to rely only on public funds for innovating in the water sector. Indeed, the majority of the interviewees were willing to participate in a water innovation model which lightens the investment risk for companies. A mixed public-private investment model has been suggested as the most effective way of financing and encouraging the renewal of water 
facilities. Under this scheme, taxes and the price of water would be the main tools to recover from the investment.

Further factors have been identified to increase innovation in the water sector in the Murcia region, including speeding up the development of remote control systems. Companies and government have highlighted the fact that control systems do not yet fully cover the whole RBD. Indeed, water supply and consumption are not monitored with the same level of accuracy throughout the region. There is a lack of reliable information on exactly how much water, where and at what rate, it is being abstracted and recharged, and, also, on what the long-term environmental implications might be. Innovations in remote control systems would reduce losses in water distribution pipes, as well as improving flood control and groundwater recharging. As stated by the EIPW [2], the smart water concept has great potential in ICT.

Kirhensteine et al. [9] argue that Spain has the greatest potential for water reuse and recycling in Europe. Denitrification and desalinisation technologies seem to be profitable markets, offering wide room for innovation. Because the region has to manage the issue of quality and quantity of water resources, innovating in denitrification and desalination would improve the balance between household demand and water consumption for economic activities. Agriculture and horticulture, which are the leading economic sectors in the region, would benefit from the increase in quality and quantity of water resources. The development of these technologies should be strongly focused on consuming less energy, as well as on providing more efficient performances. Converting technologies from pilot to process scale, would make it possible to face the chronic shortage of water and the irregularity of precipitation, matching household and agriculture demand elsewhere.

$\mathrm{TH}$ actors have highlighted further factors that are hindering innovation in the Murcia region. As well as frequent political fluctuations which discourage companies from investing in the water industry, it should not be forgotten that the EU legal framework has almost standardised the water sector. Although physiochemical features related to water issues vary a lot from territory, to territory EU standardisation tends to treat Member States in a uniform way. Therefore, companies are reluctant to introduce innovative technologies which are unprofitable to develop and commercialise because they must comply with the Law. Furthermore, from a regulatory point of view, companies innovating in the water sector, do not find the Spanish legal system is efficient. The speed at which judicial decisions are taken is essential to ensure the smooth functioning of the legal system. According to the European Commission [85], the efficiency of a legal system is determined by the length of proceedings, the clearance rate and the number of cases pending. The overall performance of Spanish civil litigation is below the EU average. Both Spanish and foreign companies are discouraged from investing in the water sector due to the slowness of such proceedings, the uncertainty of concluding cases and the costs, which often exceed the value of the claim. In response to this hindering factor, specific actions may be undertaken by the national government in order to overcome the slowness of the civil proceedings. Besides strengthening the resources and personnel allocated to the juridical system, it may be established a court in charge of managing only companies' lawsuits.

The scarcity of reward systems for companies investing in innovative water-related products and technologies, is also a hindering factor. Introducing or strengthening existing water labels could make investment in the water industry more attractive and rewarding. Labelling is an effective way of providing targeted information to the public on water performance and on sustainable water management practices [34]. A label for water no intensive products could make consumers aware of the impact on water systems that occur during production. Firms or retailers could obtain a label when their own activities and those of their suppliers, comply with prefixed criteria regarding efficient and sustainable water use. Following this scheme, successful initiatives have been already taken both in Europe and worldwide. 


\subsection{A Collaborative Approach to Innovate}

Because "science alone does not hold the power to achieve the goal of greater sustainability" [86], a collaborative approach is required to face challenges in water sector. In the TH model, individuals and organisations need to be able to generate and exploit knowledge to develop solutions that address complex issues [66,67]. Furthermore, actors should follow a transdisciplinary path [68]. More than the development of new products, innovation is the creation of new arrangements among institutions which enhance the conditions for innovation. From a general point of view, a constructive relationship between universities, companies and government should involve citizens as well, so as to obtain shared ideas for sustainable solutions. In this context, a study carried out in the Segura RBD has shown that the acceptability of innovative techniques, such as reusing water, increases when the population is informed about the cost of traditional supplies and the cost savings which could result from reusing water [13].

Raising awareness among citizens regarding water issues should speed up a more informed collaborative approach between stakeholders. In this context, schools can play a central role in raising awareness amongst young students. On one hand, the majority of the companies regularly organise water campaigns for both students and citizens, as well as organising on-site visits to water plants and water-related facilities. On the other hand, citizens and students are not fully aware of the importance of water as an irreplaceable resource, one which contributes to economic growth. Avoiding the loss of that resource can deliver economic benefits $[9,33]$. Furthermore, citizens often do not understand why they are paying taxes for water services and why money should be invested in innovations in the water sector. Thus, local authorities should contribute more to increase in-depth knowledge of the water cycle and related issues. To this aim, local authorities may support schools in introducing educational activities and games to inspire and interest young people about water-related issues. Engaging young students in educational opportunities about water, science and technology, can help to foster a future generation of water innovators. Besides that, new technologies can represent a successful tool to reach citizens in a smart, cheap and efficient way. Thus, local authorities may adopt social networks, blogs and newsletter, to inform citizens about the importance of preserving water, as well as inviting them to participate in the decision making process.

A collaborative approach to innovation can be also encouraged by taking part in European research projects, gaining experience from foreign partners, then sharing practices and models with stakeholders at the local level. Horizon 2020 is the EU funding programme for research and innovation and is running from 2014 to 2020 with an 80 billion Euro budget. Horizon 2020 supports SMEs through various funded research and innovation initiatives, enhancing EU international research and knowledge transfer. However, only one third of the companies interviewed had already taken part in a European project. These firms are all medium-sized or big companies which have carried out an average of more than 6 projects, either as leader or partner. Participating in EU projects has allowed companies to exploit innovative water technologies, as well as commercialising them in South Asia, China, India and South America.

In the light of the above, a cooperative and interdisciplinary approach among regional stakeholders could be strengthened through the promotion of new tools such as a digital platform for water innovation, aimed at identifying water-related issues and solutions. The digital platform could stimulate public-private partnerships based on actions to innovate in the water sector. Companies, innovation centres and universities would be willing to participate in the platform, since collaboration between different stakeholders could nurture profitable solutions for both the Murcia region and other countries with similar issues. However, the respondents have highlighted that implementing the platform could be a challenge because of the need to manage property rights carefully. Indeed, technology-based companies would be very careful about sharing information concerning marketable products and technologies with stakeholders. To prepare for the set-up of the digital platform, local authorities may arrange focus groups to strengthen the relations between local stakeholders, as well as promoting the prevention and reduction of water waste. The focus group methodology is widely 
adopted by the institutions of the European Union to shed light on environmental and sustainability issues at regional level. The focus group is a type of group meeting where in-depth interviews take place. Moreover, the format is flexible as it may vary according to the proposal, size, composition and interview procedures.

\subsection{Policy as an Innovation Tool}

The current water crisis has been caused not only by water scarcity, by intensification of economic activities, by increasing population and by unmet technology demand but rather by a lack of efficiency in water governance $[3,21]$. Since TH organizations address strategically relevant societal challenges such as water-related issues, an approach based on the THM could encourage policies for strengthening knowledge based regional innovation systems [47]. In the Murcia region, policies are, to a large extent, supporting innovation and entrepreneurship in the water sector and in environmental protection. However, there is considerable room for improvement. Furthermore, more effort is needed because different actors have different approaches to water, governance and to water governance. Indeed, universities, companies and governments, have very different interests. This diversity requires organising challenges and "puzzles for participants, analysts and policy makers to solve" [48,87].

The Murcia region has to manage the issue of the quality and quantity of water resources, matching household demand and water consumption for agriculture, industry and energy production. From a general point of view, the national and regional government, municipalities, industry, farmers, universities and technological centres, should all contribute to constructing a regional water policy. On the other hand, interviewees emphasised that, as well as private and public companies, the public administration should be involved more. This is due to the fact that the regional government, the Asociación Española de Abastecimientos de Agua y Saneamiento (AEAS) and municipalities, have the legal power to draft tenders, offer grants for $R \& D$ projects and levy taxes. Thus, the authorities should seek to use public resources in the most effective and efficient way. To evaluate the extent to which investments should be targeted to reduce water-related issues, it would be useful to consider previous contingent valuation (CV) studies eliciting willingness to pay (WTP) for a public program for the preservation of riverine and coastal zones $[32,88]$. The application of this tool can support the development of innovation policies at the local level. Also, public companies should be more involved in policy making as they can support real scale demonstration projects, which is perhaps the most important activity when developing and commercialising innovative solutions in the water sector. The contribution of private companies is irreplaceable for policy making as well. Taking advantage of the companies' experiences makes it possible to exploit all the opportunities offered by the circular economy in the water sector.

\section{Conclusions and Avenues for Future Research}

This exploratory study has investigated the on-going water crisis and the collaboration that industry-university-government can undertake to encourage innovation when facing complex water-related challenges. Drawing on the TH as a base model, this paper has analysed the role of stakeholders in a regional context: Murcia region in Southeast Spain. This approach offers deeper understanding both of how actors' synergies are linked to each other and of the potential to innovate in the water sector. This study has found that the THM offers a source of inspiration in local innovation policies where there is a real need to devise shared responses to water issues. Water is an irreplaceable resource and has a global value, because of the role it plays in improving the economy, society and the environment.

The THM is an effective tool for assessing the efforts of stakeholders towards meeting common targets. In the Murcia region the gaps between the TH actors are still large: in reality the various actors are not fully active and cooperative when seeking innovative solutions in the water sector. Indeed, stakeholders are strongly focused on their own individual targets. Thus, some major challenges are how to improve communication between TH actors; matching conflicting stakes; and developing a 
shared a common agenda for innovation. These challenges could also be partially met by employing graduates and researchers within companies, moving closer to business language and offering a fresh way of approaching the innovation process. Collective effort by TH actors is needed to make the water sector competitive and to increase market uptake. Although there is still a long way to go, it could be encouraged more.

In this setting, stakeholders should continue to explore how to promote innovation and solutions which are less cost-intensive for building or renewing water-related facilities, including water supply, sanitation and distribution. Investment costs are relevant and may only be sustainable if the added economic prosperity permits stakeholders to recover from their project funding. In response to this, any innovation model, aimed at mitigating the investment risk, should be based on mixed public-private partnerships, making the water industry more attractive for businesses. Moreover, research and innovation could provide answers to deal with water issues that should be seen as opportunities within the rapidly expanding water market. In particular, control systems, denitrification and desalination technologies, should be further improved for energy efficiency. Converting these technologies from pilot to process scale, would make it possible to deal with the chronic shortage of water and the irregularity of precipitation elsewhere, matching household and agriculture demand. The water industry should improve and turn knowledge into added value for society and markets. Crossing this "valley of death" requires an integrated approach to demonstrations and scaling-up projects, increasing acceptance of new technologies, public-private cooperation and appropriate investment. Furthermore, the relative lack of reward systems for companies investing in innovative water-related products and technologies must be overcome. To make the water industry more attractive, policy makers should enact a variety of tools, including tax exemptions, co-financed research projects and water labelling.

Given the fact that innovation requires a long-term commitment, initially TH synergies could be temporary, or partial, encouraging only specific stages of innovation processes. Thus, procedures concerning cooperation should also be flexible. Later, the TH collaboration could focus on taking innovation to a higher level, developing a long-term vision. However, relations between industry-university and government, need to move beyond mere technology transfer, the creation of new business and venture capital provision. Actors should also create new arrangements which improve the conditions for innovation, involving ordinary citizens as well, so as to get shared ideas for sustainable solutions. The need to find a balance between economic activities and environmental protection would lead to multiple connections and raise awareness of the social acceptability of water reuse technologies, issues and benefits. A cooperative and interdisciplinary approach among regional stakeholders could be strengthened through the promotion of new tools, such as a water innovation platform aimed at identifying water-related issues and new solutions at a local level. The platform could also encourage public-private partnerships based on actions to innovate in the water sector.

As water links several sectors at both the global and regional levels, it is important to understand how local policymakers can support industries, universities and society. To this end, it could be suggested that stakeholders in the water industry should be involved from the earliest stages of policy discussions. Taking advantage of the companies' experience makes it possible to take the opportunities offered by the circular economy of water sector. Furthermore, innovation policies in the water sector should carefully combine different areas, including: finance, entrepreneurial support, use of resources, public-private partnership and education. Innovation policies should be undertaken in a more coherent manner, avoiding fragmentation and the waste of resources. In addition, universities, industries and government bodies should synchronise their work so as to increase both the level of innovation and the transferability of technologies to the water market. How will this collaboration turn out? We cannot know today. However, "innovation typically comes from the fringes of an organisation and/or through the cross-pollination of ideas from different disciplines. We need to invite such thinking outside traditional silos and structures" [89]. 
At the end of this paper, it is important to acknowledge some limitations. The paper is based on a case study research, which is a highly qualitative form of inquiry. In addition case study research is often seen as a second-best choice because of the limited level of external validity it offers. Indeed, a single case study does not make it possible to generalise the outcomes. However, this case study emphasizes the importance of a THM as a means of encouraging a collaborative and interdisciplinary approach, which would enable both the innovation and commercialisation of technologies in the water sector, as well as identifying both the opportunities and constraints of the process. Additional research, based on more interviews and strengthened by quantitative analysis, could further support companies-universities-government to enhance the level of coordinated effort in the water sector by utilizing THM. From a general point of view, it would be interesting to assess how much TH relations have contributed to the overall development of the water sector in the Murcia region. To this aim, it would be useful to check the number of inventions, non-disclosure agreements (NDA) and patents in the water sector, deriving from the cooperation between regional stakeholders in the last ten years. This would allow to evaluate the impact of TH relations in economic terms, as well as figuring out the potential for innovation in the water sector. Besides that, as citizens could play a key role in fostering sustainability, it would be useful to explore a specific case of local collaboration between companies, universities, government and society. This approach would offer deeper understanding of how regional stakeholders have promoted the public engagement, which is crucial in the transition towards sustainable water management.

Author Contributions: L.C. conceived the research framework and wrote the paper. L.C. and F.S. jointly conceived the questionnaire and revised the paper.

Funding: This work was supported by the European Union under the Horizon 2020-Marie Sklodowska Curie Actions-RISE, "ALICE-AcceLerate Innovation in urban waste water management for Climate changE" (Grant Agreement n. 734506-CUP D82F16001100006).

Acknowledgments: The author is grateful to all stakeholders who contributed to this exploratory study, either by completing the questionnaire, or by personal interview. The author acknowledges ALICE the project partners for their valuable comments and contributions.

Conflicts of Interest: The author declares no conflict of interest. The funders had no role in the design of the study; in the collection, analyses, or interpretation of data; in the writing of the manuscript, or in the decision to publish the results.

\section{Appendix A}

\section{Questionnaire for companies in charge of providing water services in the Murcia region}

1. Please describe your company (role, activities, personnel involved).

2. According to your opinion, what do you think about the support for entrepreneurship and innovation in the water sector in the Murcia region?

Please, list in order three factors of strength and three factors of weakness regarding innovation in your Region.

3. Are public bodies such as, Region, municipalities, public companies, universities, innovation centres, schools, associations, collaboratively seeking solutions to challenges in the water sector?

In which way?

4. With which public bodies (Region, municipalities, public companies, universities, innovation centres, schools, associations) are you most regularly engaged?

Why?

5. According to your experience, how do you rate the role of university in boosting innovation in the water sector? 
Why?

6. Which other body do you find useful?

Why?

7. Does any public body, currently or previously, support the company?

If yes, please indicate which one.

8. Are you willing to participate in a water innovation model which lightens the investment risk for companies?

Do you have any comments?

9. Would you value a co-creative approach to problem solving in the water sector? (From a general point of view, co-creation is a cooperative and constructive relationship between companies, citizens, government and university. This process aims to share ideas and develop sustainable solutions to address complex challenges such as water sector issues).

Do you have any comments?

10. Base on your experience, in what areas of the water sector is accelerated innovation necessary?

Do you have any comments?

11. Please tick in order of importance, which of the following criteria do you use to assess new products and innovation in the water sector?

-Life-cycle energy cost

-Running cost

-Plant incorporation

-Infrastructure cost

12. Have you participated in any European project related to the water sector?

If yes, did you participate as leader or partner?

How do you rate the collaboration with university?

Do you have any comments?

13. According to your experience, what are the current challenges of the water sector in the Murcia region?

Do you have any comments?

14. From your point of view, which bodies (Region, municipalities, public and private companies, university, innovation centres, associations, schools) could play a key role in facing water issues?

Why?

15. Base on your experience, are policies supporting innovation in the water sector?

What policies would be useful in order to enhance the water sector? 


\section{References}

1. European Commission (EC). A Blueprint to Safeguard Europe's Water Resources; European Commission: Brussels, Belgium, 2012; pp. 1-24.

2. European Innovation Partnership Water (EIPW). Strategic Implementation Plan; European Innovation Partnership Water: Brussels, Belgium, 2012; pp. 1-22.

3. Pahl-Wostl, C.; Lebel, L.; Knieper, C.; D'Haeyer, T. D. 2.3: Synthesis Report: Context-Sensitive Comparative Analysis of Associations between Water Governance Properties and Performance in Water Management; Osnabrück: Lower Saxony, Germany, 2012.

4. European Commission (EC). Ninth Report on the Implementation Status and the Programmes for Implementation (as Required by Article 17) of Council Directive 91/271/EEC Concerning Urban Waste Water Treatment; European Commission: Brussels, Belgium, 2017; pp. 1-18.

5. Bogardi, J.J.; Dudgeon, D.; Lawford, R.; Flinkerbusch, E.; Meyn, A.; Pahl-Wostl, C.; Vielhauer, K.; Vorosmary, C. Water security for a planet under pressure: Interconnected challenges of a changing world call for sustainable solutions. Curr. Opin. Environ. Sustain. 2011, 4, 35-43. [CrossRef]

6. Mediterranean Wastewater Reuse Working Group (MED WWR WG). Mediterranean Wastewater Reuse Report. Annex B Case Studies. 2007. Available online: http://ec.europa.eu/environment/water/waterurbanwaste/info/pdf/final_report_annex_b.pdf (accessed on 2 November 2018).

7. Martins, G.; Brito, A.G.; Nogueira, R.; Ureña, M.; Fernández, D.; Luque, F.J.; Alcáce, C. Water resources management in southern Europe: Clues for a research and innovation based regional hypercluster. J. Environ. Manag. 2013, 119, 76-84. [CrossRef] [PubMed]

8. European Environment Agency (EEA). Water Resources Across Europe-Confronting Water Scarcity and Drought. Report No 2/2009; European Environment Agency: Copenhagen, Denmark, 2009.

9. Kirhensteine, I.; Cherrier, V.; Jarritt, N.; Farmer, A.; De Paoli, G.; Delacamara, G.; Psomas, A. EU-Level Instruments on Water Reuse. Final Report to Support the Commission's Impact. Assessment; Publications Office of the European Union: Luxembourg, 2016; pp. 1-292. [CrossRef]

10. Fawell, J.; Le Corre, K.; Jeffrey, P. Common or independent? The debate over regulations and standards for water reuse in Europe. Int. J. Water Resour. D 2016, 32, 559-572. [CrossRef]

11. Dinar, A. Economy-Wide Implications of Direct and Indirect Policy Interventions in the Water Sector Lessons from Recent Work and Future Research Needs; Policy Research Working Paper 6068; The World Bank Development Research Group Environment and Energy Team: Washington, DC, USA, 2012.

12. Sanz, L.A.; Gawlik, B.M. Water Reuse in Europe Relevant Guidelines, Needs for and Barriers to Innovation. European Commission Joint Research Centre Institute for Environment and Sustainability; Publications Office of the European Union: Luxembourg, 2014. [CrossRef]

13. European Union Waters Directors (EUWD). Common Implementation Strategy for the Water Framework Directive and the Floods Directive; Guidelines on Integrating Water Reuse into Water Planning and Management in the Context of the WFD; European Union Waters Directors (EUWD): Luxembourg, 2016; Available online: http://ec.europa.eu/environment/water/pdf/Guidelines_on_water_reuse.pdf (accessed on 2 November 2018).

14. Conti, A.; Gaule, P. Is the us outperforming Europe in university technology licensing? A new perspective on the European paradox. Res. Policy 2011, 40, 123-135. [CrossRef]

15. Barbieri, E.; Rubini, L.; Micozzi, A. Evaluating policies for innovation and university-firm relations. An investigation on the attitude of Italian academic entrepreneurs towards collaborations with firms. Econ. Marche J. Appl. Econ. 2013, 32, 17-45.

16. Committee of the Regions (CoR). Fostering Innovation at Regional Level: Lessons from the European Entrepreneurial Region (EER) Experience; Committee of the Regions: Luxembourg, 2015.

17. Organisation for Economic Co-operation and Development (OECD). Regions and Innovation Policy; OECD Publishing: Paris, France, 2011.

18. Kohler-Koch, B. Regions as Political Actors in the Process of European Integration; Mannheim Centre for European Social Research: University of Mannheim: Mannheim, Germany, 1993.

19. Etzkowitz, H.; Leydesdorff, L. Universities in the Global Knowledge Economy. A Triple Helix of University-Industry-Government Relations; Cassell: New York, NY, USA; London, UK, 1997. 
20. Etzkowitz, H.; Carvalho de Mello, J.M. The rise of a triple helix culture innovation in Brazilian economic and social development. Int. J. Technol. Manag. Sustain. Dev. 2004, 2, 159-171. [CrossRef]

21. Rodrigues, C.; Melo, A. The Triple Helix Model as an instrument of local response to the economic crisis. Eur. Plan. Stud. 2012, 20, 1483-1496. [CrossRef]

22. Rodrigues, C.; Melo, A. The Triple Helix Model as inspiration for local development policies: An experience-based perspective. Int. J. Urban Reg. 2013, 37, 1675-1687. [CrossRef]

23. European Commission (EC). Eighth Report on the Implementation Status and the Programmes for Implementation (as Required by Article 17) of Council Directive 91/271/EEC Concerning Urban Waste Water Treatment; European Commission: Brussels, Belgium, 2016.

24. Hoekstra, A.Y. The global dimension of water governance: Why the river basin approach is no longer sufficient and why cooperative action at global level is needed. Water 2011, 3, 21-46. [CrossRef]

25. De Pablos Heredero, C.; Bermejo Ruiz, H.M. Fostering innovation in the national systems: An application to Spain. Bus. Syst. Res. 2014, 5, 110-124. [CrossRef]

26. Rabadán, A.; Sáez-Martínez, F.J. Why European entrepreneurs in the water and waste management sector are willing to go beyond environmental legislation. Water 2017, 9, 151. [CrossRef]

27. Yin, R.K. Case Study Research: Design and Methods; Sage: London, UK, 1994.

28. Stake, R.E. The Art of Case Study Research; Sage: London, UK, 1995.

29. Danish Agency for Science, Technology and Innovation (DASTI). An OECD Horizon Scan of Megatrends and Technology Trends in the Context of Future Research Policy; DASTI: Kopenhagen, Denmark, 2016; Available online: http:/ / ufm.dk/en/publications/2016/ files/an-oecd-horizon-scan-of-megatrends-and-technologytrends-in-the-context-of-future-research-policy.pdf (accessed on 2 November 2018).

30. Ricci, A.; Sessa, C.; Weber, M. New Horizons: Future Scenarios for Research E Innovation Policies in Europe; Publications Office of the European Union: Luxembourg, 2017. [CrossRef]

31. García-Ruiz, J.M.; López-Moreno, J.I.; Vicente-Serrano, S.M.; Lasanta-Martínez, T.; Beguería, S. Mediterranean water resources in a global change scenario. Earth-Sci. Rev. 2011, 105, 121-139. [CrossRef]

32. Taylor, T.; Longo, A. Valuing algal bloom in the black sea coast of Bulgaria: A choice experiments approach. J. Environ. Manag. 2010, 91, 1963-1971. [CrossRef] [PubMed]

33. European Commission (EC). Conference report. In Proceedings of the 4 th European Water Conference, Brussels, Belgium, 23-24 March 2015; Available online: http://ec.europa.eu/environment/water/ 2015conference/pdf/report.pdf (accessed on 2 November 2018).

34. European Commission (EC). Addressing the Challenge of Water Scarcity and Droughts in the European Union; European Commission: Brussels, Belgium, 2007.

35. Kampragou, E.; Apostolaki, S.; Manoli, E.; Froebrich, J.; Assimacopoulos, D. Towards the harmonization of water-related policies for managing drought risks across the EU. Environ. Sci. Policy 2011, 14, 815-824. [CrossRef]

36. Ministerio de Agricultura, Pesca y Alimentación (MAPA). The Water Governance System of Spain; MAPA: Madrid, Spain, 2014; Available online: https: / / www.mapama.gob.es/es/ (accessed on 2 November 2018).

37. Organisation for Economic Co-Operation and Development (OECD). OECD Environmental Performance Reviews; OECD Publishing: Paris, France, 2015.

38. Etzkowitz, H.; Webster, A.; Gebhardt, C.; Cantisano Terra, B.R. The future of the university and the university of the future: Evolution of ivory tower to entrepreneurial paradigm. Res. Policy 2000, 29, 313-330. [CrossRef]

39. Ministerio de Agricultura, Pesca y Alimentación (MAPA). Innovación e Investigación en el Sector del Agua. Lineas Estratégicas; MAPA: Madrid, Spain, 2015; Available online: https:/ /www.mapama.gob.es/es/agua/ temas/sistema-espaniol-gestion-agua/documentoidiaguadiciembre2015v3_tcm30-216102.pdf (accessed on 2 November 2018).

40. WRc. European Level Report: Evaluation of the Contribution of Operational Programmes to the Implementation of EU Water Policy; European Commission: Brussels, Belgium, 2017; Available online: http:/ / ec.europa. eu/environment/water/pdf/EU_overview_report_\%20operational_programmes\%20.pdf (accessed on 2 November 2018).

41. Barrie, J.; Zawdie, G.; João, E. Leveraging triple helix and system intermediaries to enhance effectiveness of protected spaces and strategic niche management for transitioning to circular economy. Int. J. Technol. Manag. Sustain. Dev. 2017, 16, 25-47. [CrossRef] 
42. Leydesdorff, L. The Triple Helix, Quadruple Helix and an n-tuple of helices: Explanatory models for analyzing the knowledge-based economy? J. Knowl. Econ. 2012, 3, 25-35. [CrossRef]

43. Etzkowitz, H. The Triple Helix: University-industry-government innovation in action. Pap. Reg. Sci. 2011, 90, 441-442. [CrossRef]

44. Mroczkowski, T.; Miller, M. Envisioning smart development in poland from a triple helix systems perspective: A critical assessment of the Morawiecki Plan. J. Knowl. Econ. 2017, 8, 513-535. [CrossRef]

45. Lowe, C.U. The triple helix-NIH, industry, and the academic world. Yale J. Biol. Med. 1982, 55, $239-246$. [PubMed]

46. Sábato, J.; Mackenzi, M. La Produccion de la Technologia: Autónoma o Transnacional; Editorial Nueva Imagen: Ciudad de México, Mexico, 1982; pp. 1-289.

47. Etzkowitz, H.; Ranga, M. A Triple Helix System for knowledge-based regional development: From "spheres" to "spaces". In Proceedings of the VIII Triple Helix Conference, Madrid, Spain, 20-22 October 2010; Available online: https: / / www.semanticscholar.org/paper / A-Triple-Helix-System-for-Knowledge-based-RegionalEtzkowitz-Ranga/c11af7992f6dadb7a5fd6d5de6e38f1496c5381c (accessed on 2 November 2010).

48. Etzkowitz, H.; Leydesdorff, L. The dynamics of innovation: From National Systems and Mode 2 to a Triple Helix of university industry-government relations. Res. Policy 2000, 29, 109-123. [CrossRef]

49. Lew, Y.K.; Khan, Z.; Cozzio, S. Gravitating toward the quadruple helix: International connections for the enhancement of a regional innovation system in Northeast Italy. RED Manag. 2018, 48, 44-59. [CrossRef]

50. Kolehmainen, J.; Irvine, J.; Stewart, L.; Karacsonyi, Z.; Szabó, T.; Alarinta, J.; Norberg, A. Quadruple Helix, innovation and the knowledge-based development: Lessons from remote, rural and less-favoured regions. J. Knowl. Econ. 2016, 7, 23-42. [CrossRef]

51. Suvinen, N.; Konttinen, J.; Nieminen, M. How necessary are intermediary organizations in the commercialization of research? Eur. Plan. Stud. 2010, 18, 1365-1389. [CrossRef]

52. Etzkowitz, H. The new visible hand: An assisted linear model of science and innovation policy. Sci. Public Policy 2006, 33, 310-320. [CrossRef]

53. Farinha, L.; Ferreira, J. Triangulation of the Triple Helix: A conceptual framework for regional competitiveness focused on innovation and local entrepreneurship. In Proceedings of the Triple Helix 10th International Conference, Emerging Triple Helix Models for Developing Countries, Bandung, Indonesia, 8-10 August 2012.

54. Birkner, Z.; Máhr, T.; Rodek Berkes, N. Changes in responsibilities and tasks of universities in regional innovation ecosystems. Naše Gospodarstvo Our Econ. 2017, 63, 15-21. [CrossRef]

55. Schumpeter, J.A. The Theory of Economic Development; Harvard University Press: Cambridge, MA, USA, 1939.

56. Drucker, P.F. Innovation opportunities. Harv. Bus. Manag. 2003, 5-6, 28-34.

57. Karlsson, C.; Johansson, B. Towards a Dynamic Theory for the Spatial Knowledge Economy. Available online: https:/ /ideas.repec.org/p/hhs/cesisp/0020.html (accessed on 12 November 2018).

58. Porter, M.E. Competitive Strategy; Harvard University Press: Boston, MA, USA, 1985.

59. Etzkowitz, H. MIT and the Rise of Entrepreneurial Science; Routledge: London, UK, 2002.

60. Viale, R.; Etzkowitz, H. The Capitalization of Knowledge; Edward Elgar: Cheltenham, UK, 2010.

61. Porter, M.E.; Stern, S. Innovation: Location matters. Sloan Manag. Rev. 2001, 42, 28-36.

62. Farinha, L.; Ferreira, J.; Gouveia, B. Networks of innovation and competitiveness: A Triple Helix case study. J. Knowl. Econ. 2014, 7, 259-275. [CrossRef]

63. Nelson, R. National Innovation Systems; A Comparative Analysis; Oxford University Press: New York, NY, USA, 1993.

64. Saxenian, A.L. Regional Advantage: Culture and Competition in Silicon Valley and Route 128; Harvard University Press: Cambridge, MA, USA, 1994.

65. Hämäläinen, T.; Schienstock, G. Transformation of the Finnish Innovation System: A Network Approach; Suomen itsenäisyyden juhlarahasto, SITRA: Helsinki, Finland, 2001.

66. Boreham, N.; Lammont, N. Work Process Knowledge in Technological and Organizational Development. Final Report, Framework Programme IV, Targeted. Socio-Economic Research Programme; European Union Directorate-General XII: Brussels, Belgium, 2000.

67. Poppe, K.J.; Termeer, C.; Slingerland, M. Transitions Towards Sustainable Agriculture and Food Chains in Peri-Urban Areas; Wageningen Academic Publishers: Wageningen, The Netherlands, 2009. [CrossRef] 
68. Geerling-Eiff, F.A.; Hoes, A.C.; Dijkshoorn-Dekker, M.W.C. Triple helix networks matching knowledge demand and supply in seven Dutch horticulture Greenport regions. Stud. Agric. Econ. 2017, 119, $34-40$. [CrossRef]

69. Macleod, C.J.A.; Scholefield, D.; Haygarth, P.M. Integration for sustainable catchment management. Sci. Total Environ. 2007, 373, 591-602. [CrossRef] [PubMed]

70. Arahuetes Hidalgo, A. Potential for diversification of water resources in the context of climate change in the Southeast of Spain. In Proceedings of the IWA Regional Conference on Water Reuse and Salinity Management, Murcia, Spain, 11-15 June 2018.

71. Zarzo Martinez, D. El Nuevo Marco de la Reutilización de Aguas en Europa, ¿hacia donde vamos? In Proceedings of the III jornada agua y sostenibilidad. La reutilización de aguas en españa y europa. pasado, presente y futuro, Murcia, Indonesia, 15 December 2016.

72. Kuriqi, A.; Kuriqi, I.; Poci, E. Simulink programing for dynamic modelling of activated sludge process: Aerator and settler tank case. Fresen. Environ. Bull. 2016, 25, 2891-2899.

73. Kuriqi, A. Simulink application on dynamic modeling of biological waste water treatment for aerator tank case. Int. J. Sci. Technol. Res. 2014, 3, 69-72.

74. Eisenhardt, K.M.; Graebner, M.E. Theory building from cases: Opportunities and challenges. Acad. Manag. J. 2007, 50, 25-32. [CrossRef]

75. Höglund, L.; Linton, G. Smart specialization in regional innovation systems: A quadruple helix perspective. RED Manag. 2017, 48, 60-72. [CrossRef]

76. Gioia, D.A.; Corley, K.G.; Hamilton, A.L. Seeking qualitative rigor in inductive research. Organ. Res. Methods 2013, 16, 15-31. [CrossRef]

77. Barratt, M.; Choi, T.Y.; Li, M. Qualitative case studies in operations management: Trends, research outcomes, and future research implications. J. Oper. Manag. 2011, 29, 329-342. [CrossRef]

78. Rossman, R.B.; Rallis, S.F. Learning in the Field: An Introduction to Qualitative Research; Sage: Thousand Oaks, CA, USA, 1998.

79. Tellis, W. Application of a case study methodology. Qual. Rep. 1997, 3, 1-17.

80. Groves, R.M.; Fowler, F.J., Jr.; Couper, M.P.; Lepkowski, J.M.; Singer, E.; Tourangeau, R. Survey Methodology; John Wiley \& Sons: Hoboken, NJ, USA, 2013.

81. Creswell, J.W. Research Design; SAGE: London, UK, 2013.

82. Huggins, R.; Johnston, A.; Steffenson, R. Universities, knowledge networks and regional policy. J. Reg. Econ. Soc. 2008, 1, 321-340. [CrossRef]

83. Larsen, M.T. The implications of academic enterprise for public science: An overview of the empirical evidence. Res. Policy 2011, 40, 6-19. [CrossRef]

84. European Commission (EC). The Water Framework Directive and the Floods Directive: Actions Towards the 'Good Status' of EU Water and to Reduce Flood Risks; European Commission: Brussels, Begium, 2015; pp. 1-14.

85. European Commission (EC). The 2018 EU Justice Scoreboard; Publications Office of the European Union: Luxembourg, 2018; pp. 1-64. [CrossRef]

86. Lubchenco, J. Entering the century of the environment: A new social contract for science. Science 1998, 279, 491-497. [CrossRef]

87. Gustafsson, R.; Jarvenpaa, S. Extending community management to industry-university-government organizations. RED Manag. 2018, 48, 121-135. [CrossRef]

88. Alberini, A.; Rosato, P.; Longo, A.; Zanatta, V. Information and willingness to pay in a contingent valuation study: The value of S. Erasmo in the Venice Lagoon. J. Environ. Plan. Manag. 2005, 48, 155-175. [CrossRef]

89. Cufaude, J. Break out of the silo mentality. Psychologist 2015, 28, 638-641. Available online: http: / / www. asaecenter.org/Resources/ANowDetail.cfm?ItemNumber=46320 (accessed on 2 November 2018).

(C) 2018 by the authors. Licensee MDPI, Basel, Switzerland. This article is an open access article distributed under the terms and conditions of the Creative Commons Attribution (CC BY) license (http://creativecommons.org/licenses/by/4.0/). 